\title{
Effects of $\mathrm{PM}_{10}$ in human peripheral blood monocytes and $\mathbf{J 7 7 4}$ macrophages
}

\author{
DM Brown*1, K Donaldson $^{2}$ and V Stone ${ }^{1}$
}

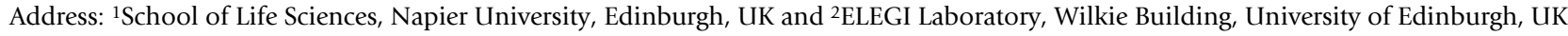 \\ Email: DM Brown* - da.brown@napier.ac.uk; K Donaldson - da.brown@napier.ac.uk; V Stone - v.stone@napier.ac.uk \\ * Corresponding author
}

Published: 2I December 2004

Respiratory Research 2004, 5:29 doi:10.1 186/1465-9921-5-29

This article is available from: http://respiratory-research.com/content/5/I/29

(C) 2004 Brown et al; licensee BioMed Central Ltd.

This is an Open Access article distributed under the terms of the Creative Commons Attribution License (http://creativecommons.org/licenses/by/2.0), which permits unrestricted use, distribution, and reproduction in any medium, provided the original work is properly cited.
Received: 29 September 2004

Accepted: 21 December 2004

\begin{abstract}
The effects of $\mathrm{PM}_{10}$, one of the components of particulate air pollution, was investigated using human monocytes and a mouse macrophage cell line (1774). The study aimed to investigate the role of these nanoparticles on the release of the pro-inflammatory cytokine TNF- $\alpha$ and IL-I $\alpha$ gene expression. We also investigated the role of intracellular calcium signalling events and oxidative stress in control of these cytokines and the effect of the particles on the functioning of the cell cytoskeleton. We showed that there was an increase in intracellular calcium concentration in $\mathbf{7 7 4}$ cells on treatment with $\mathrm{PM}_{10}$ particles which could be significantly reduced with concomitant treatment with the calcium antagonists verapamil, the intracellular calcium chelator BAPTA-AM but not with the antioxidant nacystelyn or the calmodulin inhibitor W-7. In human monocytes, $\mathrm{PM}_{10}$ stimulated an increase in intracellular calcium which was reduced by verapamil, BAPTA-AM and nacystelyn. TNF- $\alpha$ release was increased with particle treatment in human monocytes and reduced by only verapamil and BAPTA-AM. IL-I $\alpha$ gene expression was increased with particle treatment and reduced by all of the inhibitors. There was increased F-actin staining in $\mathbf{J 7 4}$ cells after treatment with $\mathrm{PM}_{10}$ particles, which was significantly reduced to control levels with all the antagonists tested. The present study has shown that $\mathrm{PM}_{10}$ particles may exert their proinflammatory effects by modulating intracellular calcium signalling in macrophages leading to expression of pro-inflammatory cytokines. Impaired motility and phagocytic ability as shown by changes in the F-actin cytoskeleton is likely to play a key role in particle clearance from the lung.
\end{abstract}

\section{Introduction}

Increased exposure to $\mathrm{PM}_{10}$ particles is associated with adverse health effects $[1,2]$. Much of the mass of $\mathrm{PM}_{10}$ is low in toxicity and it has been suggested that, combustion-derived nanoparticles (ultrafine particles) [3-5] are a key component that drives these effects, especially inflammation. In individuals with pre-existing lung disease, inhalation of nanoparticles may induce inflammation and exacerbate respiratory and cardiovascular effects through the induction of oxidative stress and inflammation $[4,6,7]$. Rat inhalation studies using nanoparticles of various types, at high exposure, have demonstrated pulmonary fibrosis, lung tumours, epithelial cell hyperplasia, inflammation and increased cytokine expression [8-11]. 
The alveolar macrophage plays an important role in particle-mediated inflammation by phagocytosing particles and release of pro-inflammatory mediators such as the cytokine tumor necrosis factor-alpha (TNF- $\alpha$ ) [12]. The signalling mechanisms for transcription of the TNF $\alpha$ gene includes calcium-related pathways in diseases such as sepsis [13-15]. Calcium is released from the endoplasmic reticulum stores on stimulation of the cell, leading to a calcium influx across the plasma membrane via calcium channels [16]. Various pathogenic particles have been shown to produce such changes in calcium flux within the cell $[17,18]$ and a large number of pathological responses could be stimulated via such calcium signalling.

In order for macrophages to migrate and phagocytose foreign material, an intact functional cytoskeleton is necessary. The cytoskeleton is sensitive to ROS and oxidative stress, due to the presence of thiol groups located on the actin microfilaments. On oxidation, these filaments crosslink, leading to reduced cell motility, impaired phagocytosis and hence clearance of foreign material from the lung. The cytoskeleton mediates several basic cell functions: chemotaxis, migration, phagocytosis, phagosomelysosome fusion, and intracellular signalling [19-21]. Several lines of evidence suggest that changes in actin filament organisation play an important role in macrophage motility, adherence to surfaces and phagocytosis. Cellular dysfunctions associated with the cytoskeleton can cause retarded phagocytosis [22] and impaired phagosome-lysosome fusion [23], which may result in a diminished cellular killing and clearance of particles and pathogens from the lung.

The pro-inflammatory cytokine interleukin 1 (IL-1) is not normally produced by the cells of healthy individuals, exceptions being skin keratinocytes, some epithelial cells and some cells of the central nervous system. In response to inflammatory stimuli, however, there is a dramatic increase in the production of IL- 1 by macrophages and other cell types [24]. There are two distinct proteins, IL-1 $\alpha$ and IL- $1 \beta$ which are the products of two distinct genes but which recognise the same cell surface receptors [25]. IL-1 possesses a wide variety of biological activities. As well as inducing its own synthesis, IL-1 stimulates the secretion of TNF- $\alpha$ and IL-6 from macrophages/monocytes [26,27]. Normal production of IL-1 is vital for host responses to injury and infection, while prolonged secretion has been linked with a number of pathological conditions [28,29].

Our hypothesis in this study was that $\mathrm{PM}_{10}$ particles produce cytokine release and cytokine gene expression in macrophages by a process which involves calcium signalling and reactive oxygen species (ROS). Furthermore, we hypothesise that other effects of $\mathrm{PM}_{10}$, such as alterations in the cytoskeleton, are also mediated via signalling processes involving both ROS and calcium.

\section{Materials and Methods Particle Characteristics}

Collection of $\mathrm{PM}_{10}$ samples was co-ordinated by Casella Stanger, London, England. Particles were collected onto TEOM filters in Marylebone Road, London, a site which had particularly high levels of traffic and therefore high levels of primary, combustion-derived nanoparticles. Ultrafine carbon black (UfCB) was obtained from Degussa (Printex 90), the average particle size was $14 \mathrm{~nm}$. The characteristics and details of UfCB particles have been published previously [30].

\section{Particle Quantification}

A single $\mathrm{PM}_{10}$ filter was placed into a bijou bottle and 0.5 $\mathrm{ml}$ phosphate buffered saline (PBS) added. The bottle was vortexed for 4 minutes to remove the particles from the filter and the resulting suspension transferred to a clean bijou bottle. The mass of particles was assessed by densitometry. As standards, a series of dilutions of UfCB particles were made, ranging from $15.625 \mu \mathrm{g} / \mathrm{ml}$ to $1 \mathrm{mg} / \mathrm{ml}$ in saline, sonicated for 5 minutes, and $75 \mu$ of each concentration was added into triplicate groups of wells in a 96well plate. Seventy-five microlitres of $\mathrm{PM}_{10}$ sample were added into a separate triplicate group of wells. The samples and standards were then read on a plate reader at 340 $\mathrm{nm}$ and the mass of particles calculated from a linear regression of the UfCB standards.

\section{J774.AI Cell Culture}

The mouse macrophage cell line J774.A1 (a kind gift from Dr W Muller GSF, Gauting, Germany) was routinely cultured in RPMI medium (Sigma) containing 5\% foetal calf serum (FCS) and Penicillin/Streptomycin. Cells were cultured until confluency was reached and then scraped from the surface of the flasks using a cell scraper. The cells were counted and adjusted to $5 \times 10^{5} / \mathrm{ml}$ in RPMI plus $5 \%$ FCS. Sterile $10 \mathrm{~mm}$ glass cover slips were placed in each well of a 24-well plate and $1 \mathrm{ml}$ of cell suspension added to each well. Cells were incubated at $37^{\circ} \mathrm{C}$ for 24 hours prior to particle treatment.

\section{Isolation of Human Peripheral Blood Mononuclear Cells} Human peripheral blood mononuclear cells were prepared according to the protocol of Dransfield et al, [31]. In brief, two separate volumes of $40 \mathrm{ml}$ of blood were withdrawn from healthy consenting volunteers and transferred to $50 \mathrm{ml}$ sterile Falcon tubes containing $4 \mathrm{ml}$ of $3.8 \%$ sodium citrate solution. Tubes were gently inverted and centrifuged at $250 \mathrm{~g}$ for 20 minutes, the plasma removed from each tube and pooled without disturbing the cell pellet. Dextran (Pharmacia), prepared as a $6 \%$ solution in saline was warmed to $37^{\circ} \mathrm{C}$, before adding to 
the cell pellet $(2.5 \mathrm{ml} / 10 \mathrm{ml}$ cell pellet $)$ and the volume made up to $50 \mathrm{ml}$ with sterile saline. Tubes were gently mixed and the cells allowed to sediment at room temperature for 30 minutes. In order to prepare autologous serum, calcium chloride solution ( $220 \mu \mathrm{l} 1 \mathrm{M} / 10 \mathrm{ml})$, was gently mixed with the plasma and incubated in a glass tube at $37^{\circ} \mathrm{C}$ until the clot retracted. Percoll (Pharmacia) gradients were made from a stock solution of $90 \%(18 \mathrm{ml}$ Percoll $+2 \mathrm{ml}$ 10x PBS, (Life Technologies, Paisley) without calcium or magnesium) to give final concentrations of $81 \%, 70 \%$ and $55 \%$ using $1 \times$ PBS. The separating gradient was prepared by layering $2.5 \mathrm{ml}$ of $70 \%$ percoll over 2.5 $\mathrm{ml} 81 \%$ percoll. The leukocyte-rich fraction from the dextran sedimentation was transferred to sterile falcon tubes, $0.9 \%$ saline added to give a final volume of $50 \mathrm{ml}$ and the tubes centrifuged at $250 \mathrm{~g}$ for 6 minutes. The pellet was resuspended in 55\% percoll and $2.5 \mathrm{ml}$ layered over the previously prepared separating gradients. Tubes were centrifuged at $290 \mathrm{~g}$ for 20 minutes and the mononuclear cells collected from the 55/70 layer. Cells were washed twice with PBS, counted, and resuspended in RPMI medium at a concentration of $5 \times 10^{6}$ cells $/ \mathrm{ml}$ and $1 \mathrm{ml}$ added to each well of a 24 well plate. For calcium imaging, cells were also set up in 6-well plates containing a $26 \mathrm{~mm}$ diameter sterile glass coverslip. The cells were incubated for 1 hour at $37^{\circ} \mathrm{C}$, the medium removed and replaced with RPMI plus $10 \%$ autologous serum and incubated for 48 hours at $37^{\circ} \mathrm{C}$. After the second incubation, the medium was replaced and the cells incubated for a further 72 hours prior to treatment.

\section{Cell Treatments}

$\mathrm{PM}_{10}$ particles were diluted to give a final concentrations ranging from $5 \mu \mathrm{g} / \mathrm{ml}$ to $40 \mu \mathrm{g} / \mathrm{ml}$ in RPMI medium without serum and the suspension was sonicated for $5 \mathrm{~min}$ utes to disperse the particles. Cells which had been set up as described above, were washed twice with sterile PBS and $250 \mu \mathrm{l}$ of particle suspension added to appropriate wells. UfCB particles were quantified as described for the $\mathrm{PM}_{10}$ and set up in parallel with $\mathrm{PM}_{10}$ particles at similar mass concentrations with J774 cells to investigate TNF- $\alpha$ release. One well received medium only (-ve control) and one received $250 \mu \mathrm{l}$ of $1 \mu \mathrm{g} / \mathrm{ml}$ LPS (+ve control). The calcium antagonists were added concomitantly with the particles to give final concentrations of verapamil $(100 \mu \mathrm{M})$, BAPTA-AM $(50 \mu \mathrm{M}), \mathrm{W}-7(250 \mu \mathrm{M})$, trolox $(25 \mu \mathrm{M})$, and nacystelyn $(5 \mathrm{mM})$. The cells were then incubated at $37^{\circ} \mathrm{C}$ for 4 hours and the supernatants removed and stored at $80^{\circ} \mathrm{C}$ until required. The cells cultured on $10 \mathrm{~mm}$ cover slips were fixed by the addition of $3 \%$ formaldehyde.

\section{J774.AI Intracellular Calcium Measurements}

J774.A1 cells were cultured and removed from flasks as described above. Cells were pooled into a single tube, adjusted to $4.5 \times 10^{6}$ cells $/ \mathrm{ml}$ in RPMI plus $10 \%$ FCS and incubated at $37^{\circ} \mathrm{C}$ until required for the assay. One millilitre of cell suspension was transferred to an Eppendorf tube, centrifuged at $145 \mathrm{~g}$ for 2 minutes, the medium removed, the cell pellet resuspended in $1 \mathrm{ml}$ PBS and again centrifuged at $145 \mathrm{~g}$ for 2 minutes. The PBS was removed and cells resuspended in serum-free RPMI medium containing $23 \mathrm{mM}$ Hepes buffer. Cells were loaded with $1 \mu \mathrm{g} / \mu \mathrm{l}$ Fura 2-AM (Sigma) in DMSO, $2 \mu \mathrm{l} / \mathrm{ml}$ cell suspension, the tube wrapped in foil and incubated in a shaking water bath for 20 minutes at $34^{\circ} \mathrm{C}$. After incubation, the tube was centrifuged at $145 \mathrm{~g}$ for 2 minutes at $4{ }^{\circ} \mathrm{C}$, the medium removed and replaced with $1.5 \mathrm{ml}$ fresh RPMI without serum. The Fura 2-AM-loaded cells were transferred to a quartz cuvette with stirrer and placed immediately into a fluorimeter with heated block and basal fluorescence measurements obtained over a $100 \mathrm{sec}-$ ond period. The fluorimeter was set up with to give excitation wavelengths of $340 \mathrm{~nm}$ and $380 \mathrm{~nm}$, emission 510 $\mathrm{nm}$ and excitation and emission slit widths set at $5 \mathrm{~nm}$. During the experiments, the cuvette temperature was kept constant at $37^{\circ} \mathrm{C}$. After 100 seconds, $10 \mu \mathrm{l}$ appropriate treatment in RPMI medium was added to the cuvette and the experiment allowed to run for a further 1700 seconds. Treatments consisted of $\mathrm{PM}_{10}$ to give a final concentration of $10 \mu \mathrm{g} / \mathrm{ml}$ with and without the calcium antagonists at the concentrations described above. Twenty microlitres of $5 \%$ Triton solution were added to the cuvette to lyse the cells to give the maximum fluorescence (Rmax) and the experiment continued for 500 seconds. To give the minimum fluorescence value (Rmin), $15 \mu \mathrm{l}$ of 0.5 M EGTA in $3 \mathrm{M}$ Tris buffer were added to the cuvette. The experiment was terminated after a further 500 seconds. The ratio of the fluorescence measurements at excitation wavelengths of 340 and $380 \mathrm{~nm}$ were converted to calcium concentration values using the method of Grynkiewicz et al, [32].

\section{Human and mouse TNF- $\alpha$ ELISA}

The supernatants previously prepared were assayed for TNF- $\alpha$ protein content using a commercially available human TNF- $\alpha$ kit (Biosource) or mouse TNF- $\alpha$ kit (R\&D Systems) according to the manufacturer's instructions. Briefly, each well of a 96-well plate was coated overnight with capture antibody, before washing with PBS containing $0.05 \%$ tween, and then adding test supernatant to the appropriate wells in triplicate groups. After incubation for 2 hours at room temperature, the wells were washed, a detection antibody added and incubated for a further hour at room temperature. The wells were then washed with PBS/tween before addition of Horseradish peroxidase (HRP)-conjugated streptavidin and incubated for 45 minutes at room temperature. Finally, the colour was developed by adding peroxidase substrate to each well, before reading the absorbance at $450 \mathrm{~nm}$ using a Dynatec plate reader. 


\section{mRNA Extraction}

The experiments described above were also used to generate cells for total RNA extraction. After removal of the supernatant, $400 \mu \mathrm{l}$ Tri reagent (Sigma) was added to each well. The lysed cells were then scraped from the surface of the plate using a cell scraper and transferred to Eppendorf tubes. Two hundred microlitres of chloroform were added to each Eppendorf, vortexed for 15 seconds and allowed to stand at room temperature for 15 minutes. The resulting mixture was centrifuged at $12000 \mathrm{~g}$ for 15 minutes at $4^{\circ} \mathrm{C}$. The colourless upper phase was transferred to a fresh Eppendorf, before adding $450 \mu \mathrm{l}$ isopropanol. The mixed samples were allowed to stand for a further 10 minutes at room temperature. Again the tubes were centrifuged at $12000 \mathrm{~g}$ for 10 minutes at $4^{\circ} \mathrm{C}$, the supernatant removed and the RNA pellet washed in $1 \mathrm{ml}$ of $75 \%$ ethanol. The resulting samples were then vortexed briefly, centrifuged at $7500 \mathrm{~g}$ for 5 minutes at $4{ }^{\circ} \mathrm{C}$ and the RNA pellet airdried for 10 minutes. The RNA was then suspended in 50 $\mu$ diethylpyrocarbonate (DEPC)-treated water and stored at $-70^{\circ} \mathrm{C}$ until required for quantification and Reverse Transcriptase-Polymerase Chain Reaction (RT-PCR).

\section{RT-PCR}

The RT-PCR procedure was carried out using the Promega Access Kit. Briefly, a master mix of the kit reagents was prepared according to the manufacturers instructions. Ten microlitres of RNA at $0.03 \mu \mathrm{g} / \mathrm{ml}$ was added to $40 \mu \mathrm{l}$ of the master mix, containing $10 \mu \mathrm{l}$ of the appropriate human primers Glyceraldehyde Phosphate Dehydrogenase (GAPDH) or IL-1- $\alpha$ (MWG AG Biotech, Ebersberg, Germany). Tubes were placed in a thermal cycler which was programmed for the following temperatures and times. Following an initial 45 minute incubation at $48^{\circ}$, samples were cycled as follows: $94^{\circ} \mathrm{C}$ for 2 minutes, $95^{\circ} \mathrm{C}$ for 30 seconds, $60^{\circ} \mathrm{C}$ for 1 minute, $68^{\circ} \mathrm{C}$ for 2 minutes. This cycle was repeated 25 times for GAPDH and 30 times for IL-1 alpha. To conclude, the sample was incubated at $68^{\circ} \mathrm{C}$ for 7 minutes and then cooled to $4^{\circ} \mathrm{C}$. The resulting RT-PCR products were separated by electrophoresis using a $2 \%$ agarose gel containing $1 \mu \mathrm{g} / \mathrm{ml}$ ethidium bromide and viewed under UV light. The RT-PCR bands were quantified by densitometry using Syngene software and the IL$1 \alpha$ band intensity was expressed as a percentage of the corresponding GAPDH band. These results were then expressed as a percentage of the untreated control.

\section{Calcium Imaging}

Human mononuclear cells were isolated from blood as previously described followed by adhesion onto $26 \mathrm{~mm}$ glass coverslips contained in 6 -well plates. Cells were seeded in RPMI medium containing $0.1 \%$ BSA and penicillin/streptomycin at a density of $5 \times 10^{5}$ cells/ $\mathrm{ml}$ and incubated at $37^{\circ} \mathrm{C}, 5 \% \mathrm{CO}_{2}$ for 1 hour before washing with $1 \mathrm{ml}$ PBS. Prior to particle treatment and digital enhanced video microscopy (Roper scientific), cells were loaded with the calcium-sensitive dye, Fura 2-AM $(2 \mu \mathrm{g} /$ $\mathrm{ml}$ in RPMI) (Sigma) for 30 minutes at $37^{\circ} \mathrm{C}$. The coverslips were then washed with PBS, assembled into the microscope holder and $400 \mu \mathrm{l}$ RPMI medium without phenol red (Sigma) added. The fluorescence ratio was observed (excitation 340 and $380 \mathrm{~nm}$, emission $510 \mathrm{~nm}$ ) at a magnification of $63 \times$ (Zeiss Axiovert microscope). Images were captured every 2 seconds by a Coolsnap $f x$ Photometrics (Roper Scientific) camera controlled by Metafluor software. After 100 seconds particle treatment was added to the cells $(100 \mu \mathrm{l}$ of a $250 \mu \mathrm{g} / \mathrm{ml}$ stock solution of particles to give a final concentration of $50 \mu \mathrm{g} / \mathrm{ml}$ ) contained in phenol red-free RPMI medium.

\section{F-Actin Staining}

The cells cultured on cover slips and fixed with formaldehyde were washed three times with PBS and permeablised with $0.1 \%$ Triton for 4 minutes. Cells were then washed three times with PBS and the F-actin stained using $33 \mathrm{ng} /$ ml Phalloidin-FITC (Sigma) in PBS for 30 minutes at room temperature. Cells were washed three times with PBS before staining with propidium iodide $(10 \mu \mathrm{g} / \mathrm{ml}$ in PBS) for 5 seconds. Cells were further washed three times with PBS before being mounted on glass slides using Citifluor mounting medium. The cells were then examined using an Axiofluor fluorescence microscope. Images were captured and quantified using Metamorph software (Universal Imaging Corporation). Seven fields of view were captured from each treatment and the images deconvolved using the image software. The staining intensity of each cell was then measured using the analysis software.

\section{Statistical Analysis}

Data from all of the experiments were analysed using analysis of variance with Tukey or Fishers multiple comparison test. Significance was set at $\mathrm{p}<0.05$.

\section{Results Intracellular Calcium Concentration in $\mathrm{PM}_{10^{-}}$-Treated J774.AI Cells}

The effects of $\mathrm{PM}_{10}$ on $\mathrm{J774}$ murine macrophages was investigated at final concentrations of 5,10 or $25 \mu \mathrm{g} / \mathrm{ml}$ $\mathrm{PM}_{10}$. Treatment of the cells with these particles produced a dose-dependent increase in cytosolic calcium concentration $\left[\mathrm{Ca}^{2+}\right]_{\mathrm{c}}$ up to a concentration of $10 \mu \mathrm{g} / \mathrm{ml}$. At $25 \mu \mathrm{g} /$ $\mathrm{ml}$ the $\left[\mathrm{Ca}^{2+}\right]_{\mathrm{c}}$ decreased to a value similar to the $5 \mu \mathrm{g} / \mathrm{ml}$ particle concentration. (Figure 1a). Subsequent treatment with thapsigargin to release the endoplasmic reticulum calcium store produced a further increase in cytosolic $\mathrm{Ca}^{2+}$ indicating that the cells remained viable and confirming previous studies [33]. There was a statistically significant difference between control and $\mathrm{PM}_{10}$ treatments at $10 \mu \mathrm{g} /$ $\mathrm{ml}(\mathrm{p}<0.05)$. The $\left[\mathrm{Ca}^{2+}\right]_{\mathrm{c}}$ following concomitant treatment of cells with particles and calcium antagonists was 

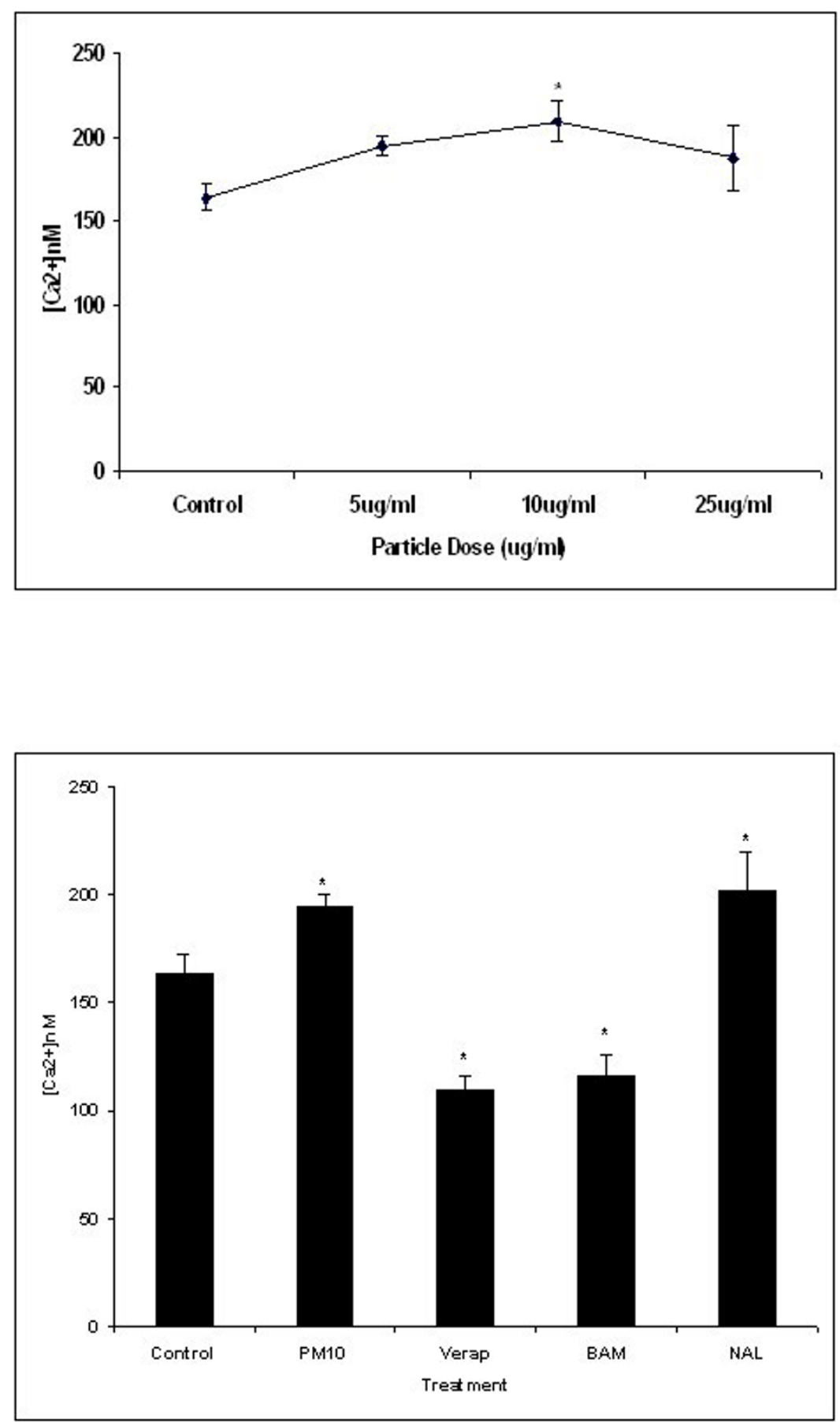

Figure I

The cytosolic calcium concentration (nM) in 3774 cells on treatment with 5-25 $\mu \mathrm{g} / \mathrm{ml}$ PM 10 particles for I700 seconds (a) and with $10 \mu \mathrm{g} / \mathrm{ml} \mathrm{PM} 10$ particles plus calcium antagonists (b). There was a significant difference only at the $10 \mu \mathrm{g} / \mathrm{ml}$ particle dose from the control $(p<0.05)$. With calcium antagonist treatment, there was a significant difference between all of the treatments and the control $(p<0.05)$. Data represents the mean \pm SEM of the intracellular calcium concentration $(n M)$. $(n=3)$. 


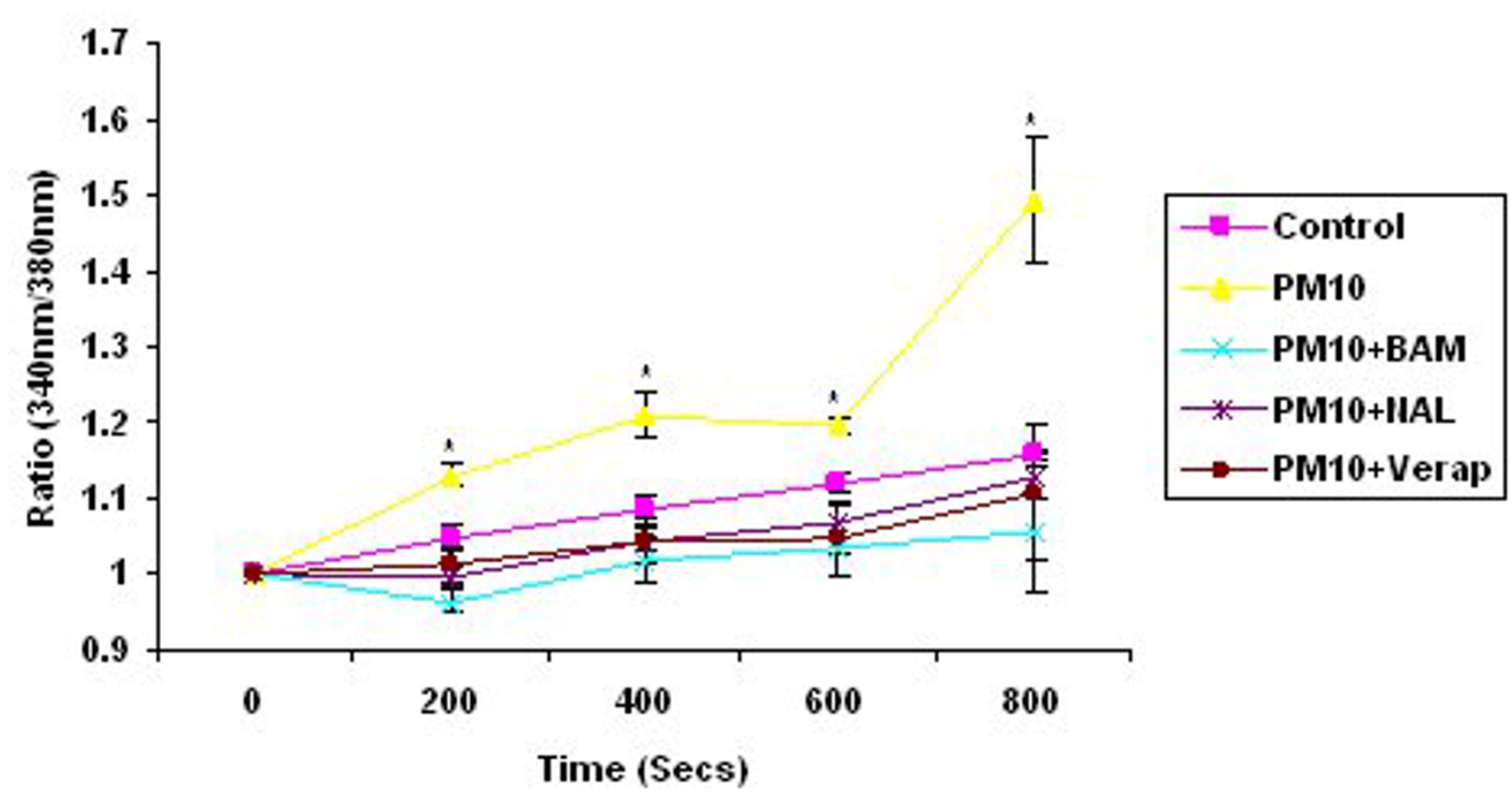

\section{Figure 2}

The intracellular calcium concentration (nM) in human monocytes on treatment with $\mathrm{PM}_{10}$ at a concentration of $10 \mu g / \mathrm{ml}$. Particles and calcium antagonists were added at zero time and the experiment run for 800 seconds in total (first 800 seconds shown). There was a significant difference between $\mathrm{PM}_{10}$-treated cells and $\mathrm{PM}_{10}$ and calcium antagonist treatment at each time point tested $(p<0.05)$. Data represents the mean \pm SEM of the ratio of $340 / 380 \mathrm{~nm}$. $(n=3)$.

reduced (figure $1 \mathrm{~b}$ ). Both the calcium channel blocker verapamil, and the calcium chelator BAPTA-AM significantly reduced $(p, 0.05)$ the intracellular calcium compared with $\mathrm{PM}_{10}$ alone. In contrast, the antioxidant Nacystelyn did not significantly reduce the $\mathrm{PM}_{10}$-stimulated $\left[\mathrm{Ca}^{2+}\right]$ increase, with $\mathrm{Ca}^{2+}$ concentration remaining significantly greater than the control value $(\mathrm{p}<0.05)$. In our previous studies [34,35] we demonstrated that the antagonists used at the same concentrations used here caused no toxic effects to cells and that the drug treatment produced similar results to the untreated controls.

\section{Intracellular Calcium Concentration in $\mathrm{PM}_{10}$-Treated Human Monocytes}

$\mathrm{PM}_{10}$ also induced a significant increase in cytosolic calcium in the primary human monocytes $(\mathrm{p}<0.05)$. The dose of $10 \mu \mathrm{g} / \mathrm{ml}$ final concentration was chosen as the dose at which a significant increase in $\left[\mathrm{Ca}^{2+}\right]_{\mathrm{C}}$ had previously been observed (figure 1a). At time points from 600 to 800 seconds after the addition of particle/antagonist treatment, there was a rapid increase in $\left[\mathrm{Ca}^{2+}\right]_{c}$ with parti- cles alone compared with the antagonists. In contrast to the antagonist treatment effects reported in figure 1, the antioxidant nacystelyn significantly inhibited the $\left[\mathrm{Ca}^{2+}\right]_{\mathrm{c}}$ changes induced in the human monocytes treated with 10 $\mu \mathrm{g} / \mathrm{ml} \mathrm{PM}_{10}$ (figure 2). Both the intracellular calcium chelator BAPTA-AM and the calcium channel blocker verapamil also significantly inhibited the $\left[\mathrm{Ca}^{2+}\right]_{\mathrm{c}}$ rise compared with particles alone $(\mathrm{p}<0.05)$.

\section{Effect of UfCB and PM 10 particles on TNF- $\alpha$ release by J774 cells}

A comparison of the gram for gram dose effect of $\mathrm{PM}_{10}$ and UfCB particles on TNF- $\alpha$ release by J774 macrophages is shown in figure 3 . The data show that $\mathrm{PM}_{10}$ particles caused significantly more TNF- $\alpha$ release as the same mass of UfCB particles by the mouse macrophage cell line.

\section{TNF- $\alpha$ release in $\mathbf{P M}_{10}$-treated Human Monocytes}

The release of TNF- $\alpha$ protein by human monocytes after treatment with varying concentrations of $\mathrm{PM}_{10}$ is shown in figure 4 . The dose of particles ranged from $5 \mu \mathrm{g} / \mathrm{ml}$ to 


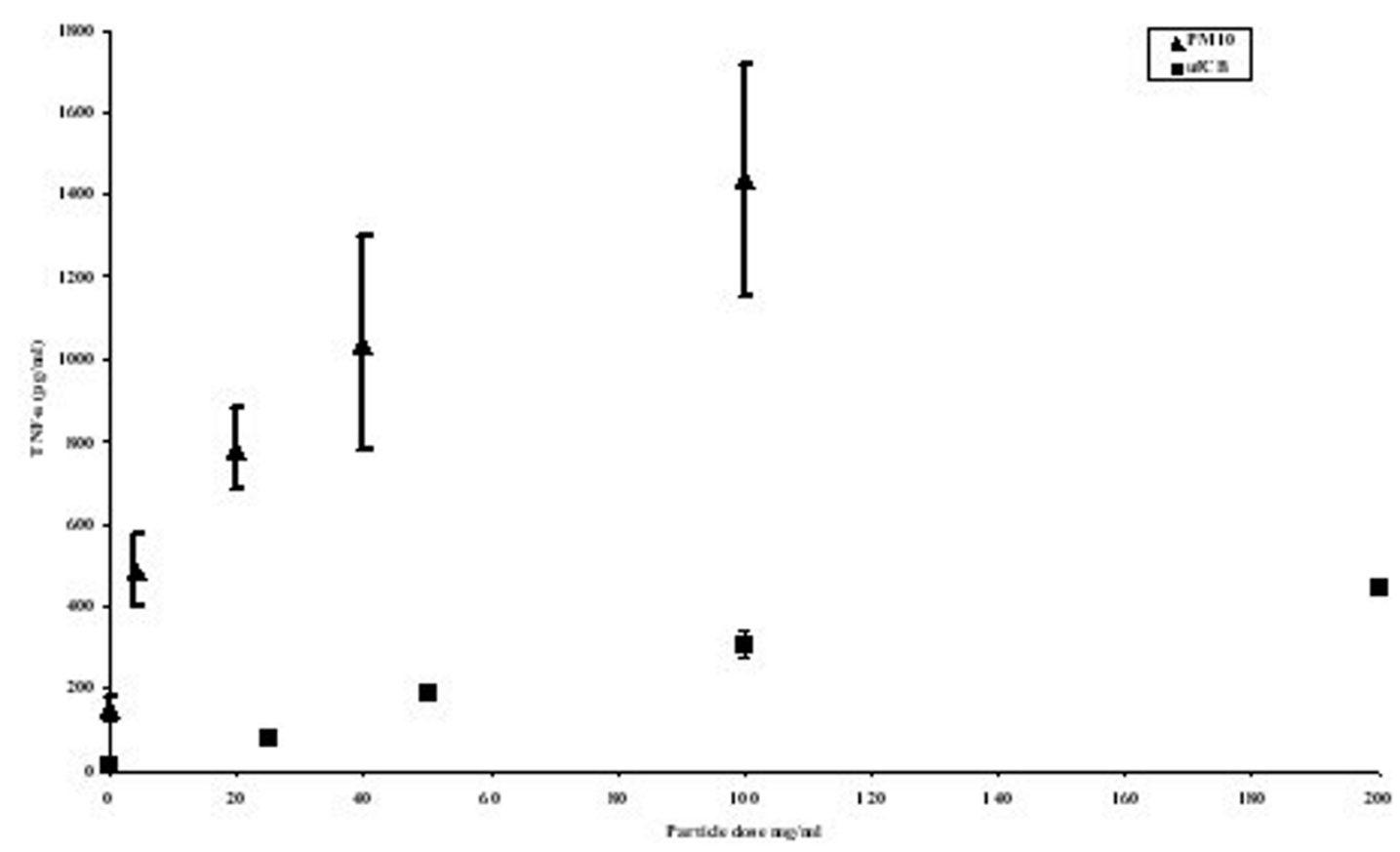

Figure 3

TNF- $\alpha$ protein release in $\mathbf{3 7 4}$ cells treated with UfCB or $\mathrm{PM}_{10}$ for 4 hours. There was significantly more TNF- $\alpha$ release in $\mathrm{PM}_{10}$ treated cells compared with an equal mass of UfCB. Data represents the mean $\pm \mathrm{SEM} p g / \mathrm{ml} T N F-\alpha$ release $(n=3)$.

$40 \mu \mathrm{g} / \mathrm{ml}$ with concomitant treatment with calcium antagonists. There was a clear dose response of particle treatment from $10 \mu \mathrm{g} / \mathrm{ml}$ to $40 \mu \mathrm{g} / \mathrm{ml}$. Within this range, the TNF- $\alpha$ concentration was approximately $170 \mathrm{pg} / \mathrm{ml}$ to $1000 \mathrm{pg} / \mathrm{ml}$. At higher particle doses, the calcium antagonists reduced TNF- $\alpha$ release only marginally with the most dramatic and significant effect being seen with a particle concentration of $10 \mu \mathrm{g} / \mathrm{ml}$ with verapamil (V) and BAPTA-AM (B) treatments which reduced TNF- $\alpha$ release to $29 \mathrm{pg} / \mathrm{ml}$ and $7 \mathrm{pg} / \mathrm{ml}$ respectively $(\mathrm{p}<0.05)$. There was no reduction in $\mathrm{PM}_{10}$ induced TNF- $\alpha$ release with $\mathrm{W}-7$ (W), Trolox (T) or Nacystelyn (N) at any particle dose tested.

\section{IL-I mRNA Expression}

Treatment of human peripheral blood monocytes with 10 $\mu \mathrm{g} / \mathrm{ml} \mathrm{PM}_{10}$ for 4 hours produced a significant increase in IL-1 $\alpha$ mRNA content compared with unstimulated cells $(\mathrm{p}<0.05)$ (figure 5). The IL-1 $\alpha$ band intensities were expressed as a percentage of the GAPDH band intensities and then normalised to the unstimulated control. $\mathrm{PM}_{10}$ induced a five fold increase in IL- $1 \alpha$ mRNA expression compared with the control and on treatment with the calcium antagonists, this was reduced to values similar to the control. There was a significant difference between the $\mathrm{PM}_{10}$ exposed cells and concomitant treatment with all of the calcium antagonists and antioxidants tested $(\mathrm{p}<$ $0.05)$.

\section{F-Actin Staining}

The fluorescence intensity of cells stained for F-actin after treatment with $\mathrm{PM}_{10}$ particles and calcium antagonists is shown in figure 6. Particles alone significantly increased the phalloidin-FITC fluorescence and hence the F-actin content of the cells compared with untreated cells. All of the calcium antagonists tested inhibited the $\mathrm{PM}_{10}$ induced increase in F-actin intensity to control levels and this was significantly different from particle only treatment $(\mathrm{p}<$ $0.05)$, although the increase in the fluorescence intensity of the $\mathrm{PM}_{10}$-treated cells was modest (a 5\% difference). 

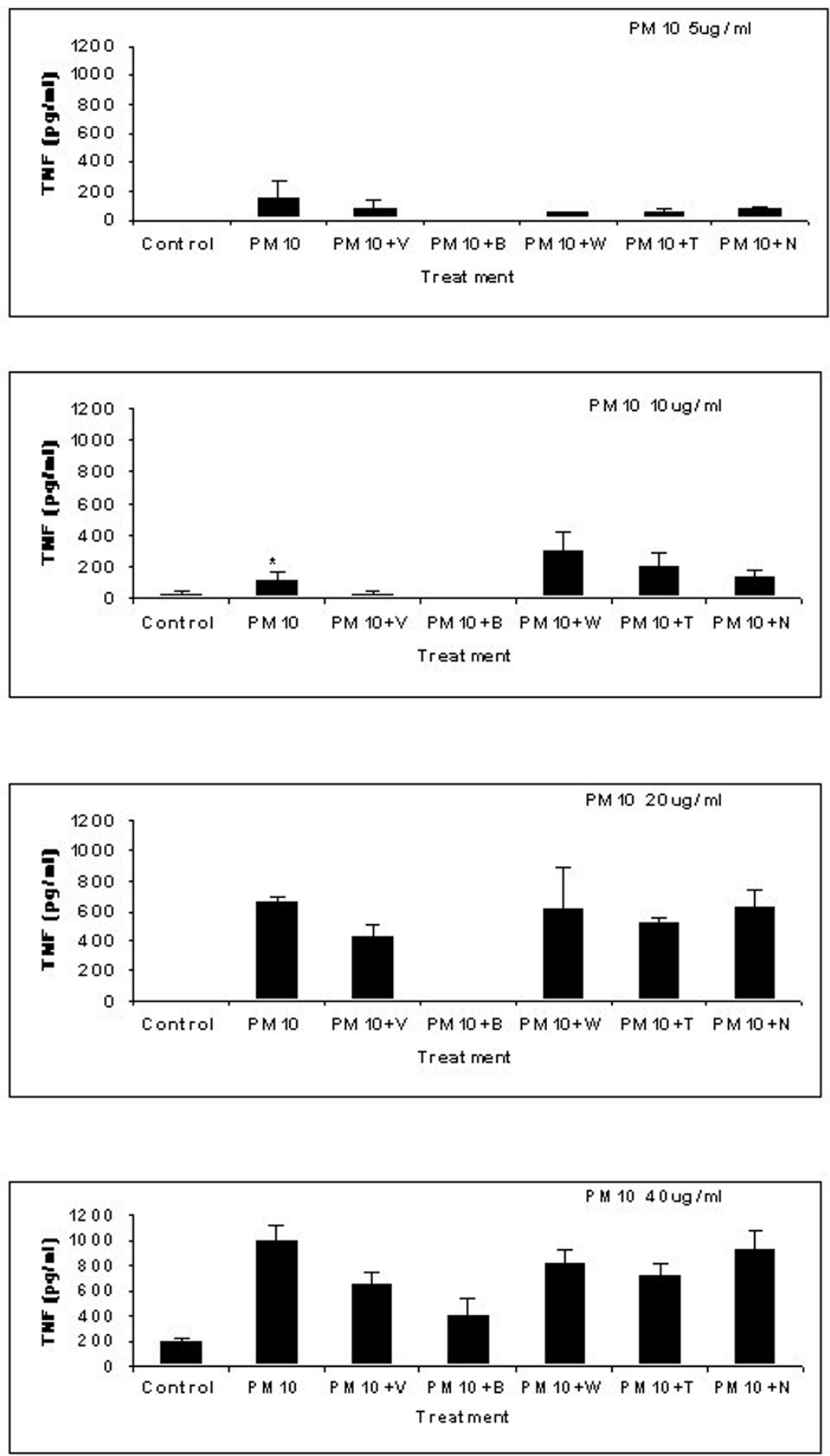

Figure 4

TNF- $\alpha$ release by human monocytes after treatment with $\mathrm{PM}_{10}(5-40 \mu \mathrm{g} / \mathrm{ml})$ and with concomitant treatment with calcium antagonists for 4 hours verapamil (V), BAPTA-AM (B), W-7 (W), trolox (T), and nacystelyn (N). There was a significant difference between the untreated control and $\mathrm{PM}_{10}$ treatment only for the $10 \mu \mathrm{g} / \mathrm{ml}$ dose $(\mathrm{P}<0.05)$. Data represents the mean \pm SEM $\mathrm{pg} / \mathrm{ml}$ TNF- $\alpha$ release $(\mathrm{n}=5)$. 

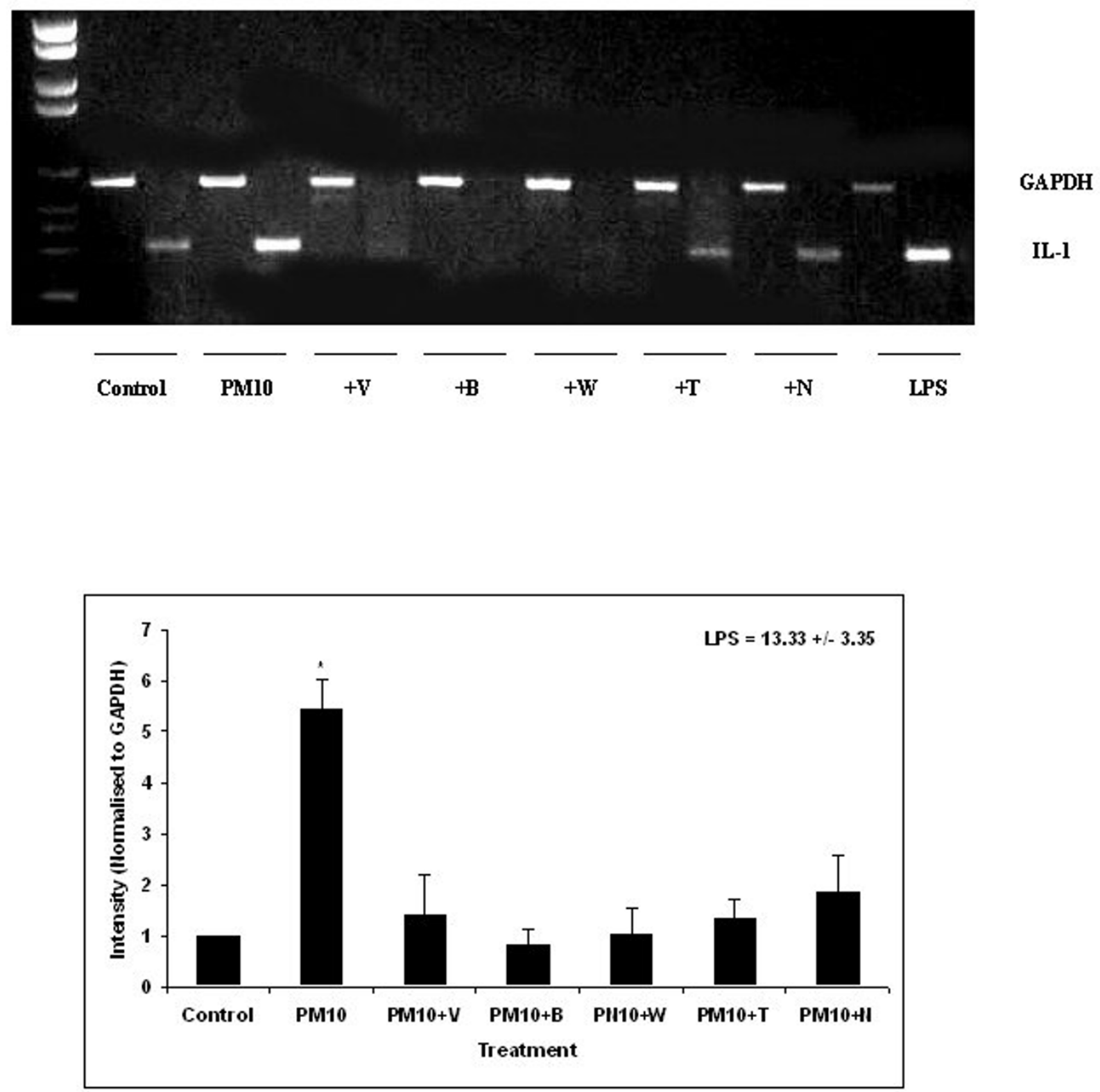

\section{Figure 5}

IL-I $\alpha$ mRNA expression in human monocytes treated with $10 \mu g / m P_{10}$ particles with and without calcium antagonists for 4 hours. The top panel shows a typical gel. The graph shows the IL-I $\alpha$ expression as a percentage of the GAPDH and normalised

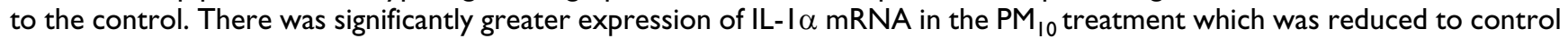
levels with calcium antagonist treatment. Data represents the mean \pm SEM of the mRNA intensity. $(n=3)$. 


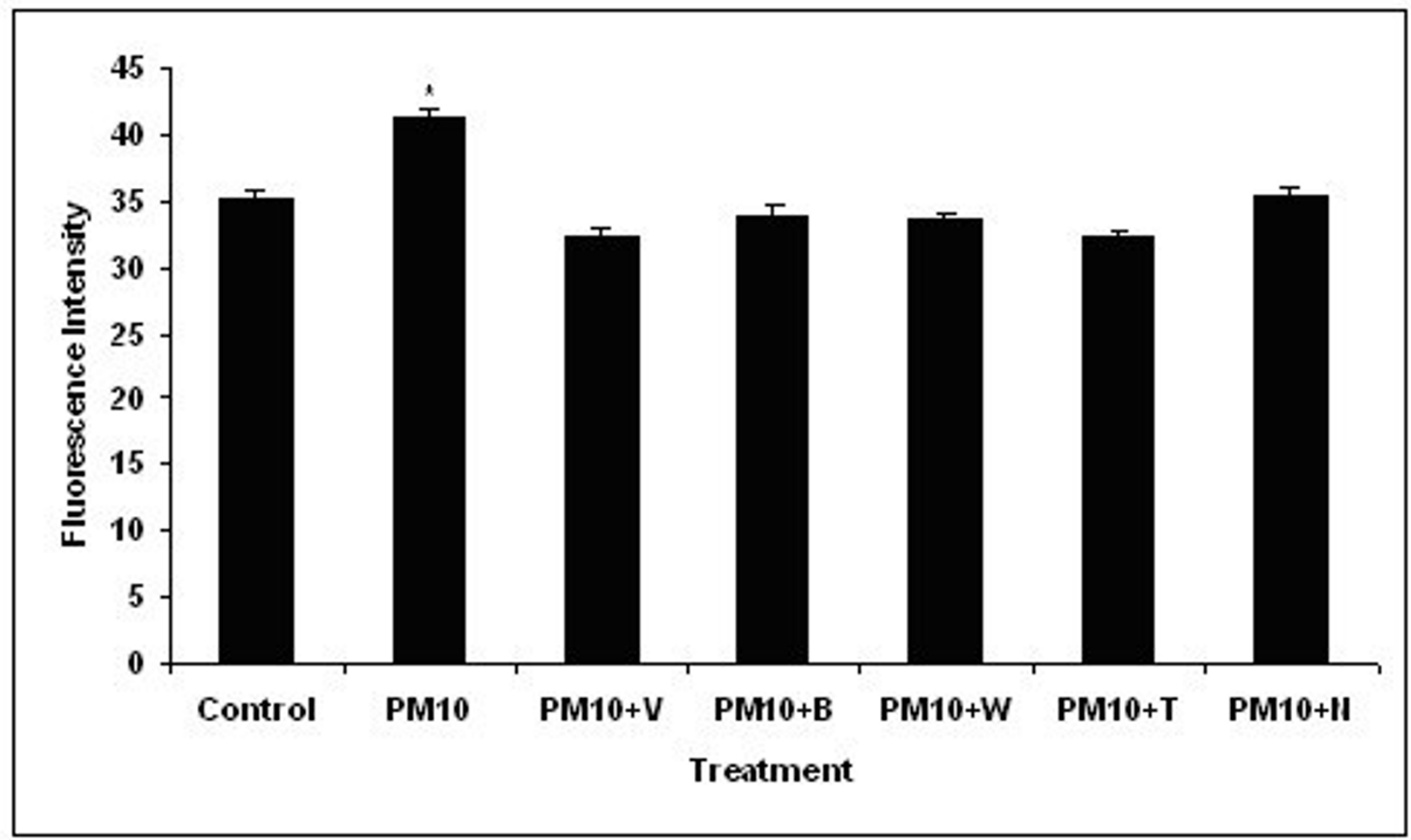

Figure 6

The fluorescence intensity of F-actin stained $\mathrm{J774}$ cells after $10 \mu \mathrm{g} / \mathrm{ml} \mathrm{PM} 10$ treatment and with calcium antagonist treatment for 4 hours. There was a significant difference in the intensity of $P M_{10}$-treated cells compared with the untreated control $(P<$ $0.05)$. There was no significant difference between the control and any other treatment. Data represents the mean \pm SEM of the fluorescence intensity of the cells. $(n=3)$.

\section{Discussion}

There is evidence that increases in particulate air pollution correlate with increased morbidity and mortality from respiratory and cardiovascular causes $[1,36-38]$ and the proinflammatory effects of $\mathrm{PM}_{10}$ are considered to drive these effects $[39,40]$. The present study aimed to investigate the effect of $\mathrm{PM}_{10}$ particles on oxidative stress- and calciumrelated cytokine regulation in human monocytes and on the cytoskeleton in mouse J774 cells.

We have previously shown that ultrafine or nanoparticles enhanced the calcium influx into cells of a monocytic cell line (MM6) $[19,34]$ and that these $\left[\mathrm{Ca}^{2+}\right]_{\mathrm{c}}$ changes lead to production of the proinflammatory cytokine TNF- $\alpha$ [35]. We demonstrate here using calcium imaging, that $\mathrm{PM}_{10}$ particles can also stimulate entry of extracellular calcium into both $\mathrm{J774}$ macrophages and human macrophage derived monocytes, and that this process is inhibited by a calcium channel blocker suggesting that the $\mathrm{PM}_{10}$, in a similar fashion to UfCB induces opening of plasma mem- brane calcium channels leading to a calcium influx. The results obtained using the antioxidant nacystelyn were confusing. In the J774 macrophages nacystelyn was unable to inhibit $\mathrm{PM}_{10}$ induced increases in cytosolic calcium concentration, whereas the same antioxidant was very effective in the human monocyte derived macrophages. This difference could be due to a species difference or a comparison between a cell line and primary cells. A number of cell lines have been demonstrated to exhibit aberrant calcium signalling pathways. Our previous studies using human macrophages suggest that ultrafine particle-induced increases in cytosolic calcium can be mediated by ROS [35] and since a large proportion of the particles within $\mathrm{PM}_{10}$ are ultrafine, it is conceivable that much of the calcium increase is ROS mediated, at least in part. However, $\mathrm{PM}_{10}$ also contains other substances, such as metals, that could influence this pathway. Metals would in fact be expected to increase the ROS production by the $\mathrm{PM}_{10}$ particles [41]. 
The present study clearly shows that the same dose of $\mathrm{PM}_{10}(10 \mu \mathrm{g} / \mathrm{ml})$ that induces calcium elevation also stimulates significant increases in both TNF- $\alpha$ protein release and IL- $1 \alpha$ mRNA production by macrophages. The calcium channel blocker verapamil and the intracellular calcium chelator BAPTA-AM reduced the calcium increase, TNF- $\alpha$ protein release and IL-1 mRNA expression by human monocytes when stimulated with $\mathrm{PM}_{10}$ particles. This is strong evidence to suggest that influx of extracellular calcium plays a key role in upregulating the proinflammatory response induced by $\mathrm{PM}_{10}$ that could lead to disease. However, the calmodulin inhibitor W-7 had little effect on TNF- $\alpha$ release, while it did inhibit IL-1 mRNA expression. The antioxidants also had variable abilities to block cytokine expression, inhibiting IL-1 mRNA production but not TNF- $\alpha$ protein release. These differences could be explained either by divergent pathways controlling expression of the two cytokines, or that TNF- $\alpha$ protein was measured in comparison to IL-1 mRNA. However, clearly both calcium and ROS are important in the regulation of IL- $1 \alpha$ mRNA expression while only calcium is important in controlling TNF- $\alpha$ expression in macrophages exposed to $\mathrm{PM}_{10}$.

These studies indicate that on an equal mass basis $\mathrm{PM}_{10}$ is far more potent that UfCB in terms of its ability to induce TNF- $\alpha$ protein release. This is likely to be due to other components, such as metals and organic compounds other than the carbon core, within $\mathrm{PM}_{10}$ that can promote inflammation. It is also possible that components such as the UF particles and metals could interact to enhance toxicity as has been shown for ROS production in vitro and inflammation in vivro [41]. Our previous studies have failed to detect LPS in the $\mathrm{PM}_{10}$ particles, therefore it is unlikely that cytokine release, changes in intracellular calcium, and IL-1 $\alpha$ gene expression can be explained solely by endotoxin.

As explained previously, the cytoskeleton is the scaffold of cells, and in the case of motile cells such as macrophages it is responsible for controlling movement. Disruption of the cytoskeleton, particularly via oxidative stress, is thought to disrupt cellular structure and hence function [42]. We have previously demonstrated that $\mathrm{PM}_{10}$ generates ROS [43]. The ability of the antioxidants trolox and nacystelyn to prevent the $\mathrm{PM}_{10}$ induced increase in F-actin staining in this study demonstrates that particle-derived ROS impact on the macrophage cytoskeleton. Our previous studies also demonstrate that Uf particle-induced ROS play a role in elevating the cytosolic calcium concentration of macrophages leading to increased TNF- $\alpha$ production [35]. The results of this study also suggest that both calcium signalling and ROS are important in modulating the F-actin cytoskeleton in response to $\mathrm{PM}_{10}$ exposure. As has been shown by other workers $[44,45]$, in both the macrophage cell line and primary cells that F-actin is distributed as microfilaments around the cell, with special prominence at the leading edge of the cells. The microtubules in contrast are situated throughout the cell. Microtubules and actin filaments have previously been studied as targets of antitumour drugs [46] which mainly work by acting on microtubules and alter the dynamics of actin filaments. Changes in the distribution of actin filaments and their expression compared with normal cells may indicate alterations in the phagocytic ability of macrophages which may eventually lead to impaired particle clearance from the lungs. We show here that treatment of macrophages with $\mathrm{PM}_{10}$ particles increased the F-actin fluorescence signal in cells stained with FITC-labelled phalloidin, although changes in the distribution of actin filaments was not apparent from microscope analysis there appeared to be more cortical staining. In accord with the role of calcium and ROS in the induction of IL-1 expression, both of these factors appeared to play an important role in modulating the F-actin cytoskeleton.

The present study has shown that $\mathrm{PM}_{10}$ particles may exert their increased pro-inflammatory effects by modulating intracellular calcium signalling in macrophages leading to expression of proinflammatory cytokines. An additional consideration is the effects of particles on the cytoskeleton of the cell. Impaired cellular motility and phagocytic ability is likely to play a key role in particle clearance from the lung, thus perpetuating the effects of $\mathrm{PM}_{10}$. The role of calcium and ROS in other cellular responses are under investigation.

\section{Acknowledgements}

This study was generously funded by the Colt Foundation.

\section{References}

I. Pope CA, Dockery DW: Epidemiology of particle effects. In Air Pollution and Health Edited by: Holgate ST, Samet JM, Koren HS, Maynard RL. Academic Press, San Diego; 1999:673-705.

2. Brunekreef B, Holgate ST: Air pollution and health. Lancet 2002, 360:1233-1242.

3. Lighty JS, Veranth JM, Sarofim AF: Combustion aerosols: factors governing their size and composition and implications to human health. J Air Waste Manag Assoc 2000, 50:1565-1618.

4. Ferin J, Oberdoster G, Penney DP: Pulmonary retention of ultrafine and fine particles in rats. Am J Respir Cell Mol Biol 1992, 6:535-542.

5. Schwartz J: Daily deaths are associated with combustion particles rather than $S O(2)$ in philadelphia [In Process Citation]. Occup Environ Med 2000, 57:692-697.

6. Seaton A, MacNee W, Donaldson K, Godden D: Particulate air pollution and acute health effects. Lancet 1995, 345:176-178.

7. Utell MJ, Frampton MW: Acute health effects of ambient air pollution: The ultrafine particle hypothesis. J Aerosol Med 2000, 13:355-359.

8. Dasenbrock C, Peters L, Creutzenberg O, Heinrich U: The carcinogenic potency of carbon particles with and without PAH after repeated intratracheal administration in the rat. Toxicol Lett 1996, 88: I5-2I.

9. Driscoll KE, Carter JM, Howard BW, Hassenbein DG, Pepelko W, Baggs RB, Oberdoster G: Pulmonary inflammation, chemokine, and mutagenic responses in rats after subchronic inhalation of carbon black. Toxicol Appl Pharmacol 1996, 136:372-380. 
10. Oberdoster G, Ferin J, Lehnert BE: Correlation between particlesize, in-vivo particle persistence, and lung injury. Environ Health Perspect 1994, I02:173-179.

I I. Nikula KJ, Snipes MB, Barr EB, Griffith WC, Henderson RF, Mauderly $\mathrm{JL}$ : Comparative pulmonary toxicities and carcinogenicities of chronically inhaled diesel exhaust and carbon black in F344 rats. Fundam Appl Toxicol 1995, 25:80-94.

12. Donaldson K, Tran CL: Inflammation caused by particles and fibres. Inhal Toxicol 2002, I4:5-27.

13. Drouet C, Shakhov AN, Jongeneel CV: Enhancers and transcription factors controlling the inducibility of the tumor-necrosis-factor-alpha promoter in primary macrophages. J Immunol I99I, I47(5): I694- I700.

14. Rhoades KL, Golub SH, Economou JS: The regulation of the human tumor-necrosis-factor-alpha promoter region in macrophage, t-cell, and b-cell lines. J Biol Chem 1992, 267(3I):22102-22107.

15. Sayeed MM: Alterations in calcium signaling and cellular responses in septic injury. New Horizons 1996, 4:72-86.

16. Hoyal CR, Giron-Calle J, Forman HJ: The alveolar macrophage as a model of calcium signaling in oxidative stress. J Toxicol Environ Health B Crit Rev 1998, I:I I7-I34.

17. Faux SP, Michelangeli F, Levy LS: Calcium chelator quin-2 prevents crocidolite-induced DNA strand breakage in human white blood cells. Mutat Res 1994, 3 I I:209-2 I5.

18. Stone V, Brown DM, Watt N, Ritchie H, Wilson M, Donaldson K: Ultrafine particle-mediated activation of macrophages: intracellular calcium signaling and oxidative stress. Inhal Toxicol 2000, I 2(suppl 3):345-35I.

19. Ding A, Sanchez E, Nathan CF: Taxol shares the ability of bacterial lipopolysaccharide to induce tyrosine phosphorylation of microtubule-associated protein kinase. J Immunol 1993, I 5 |:5596-5602.

20. Hwang S, Ding A: Activation of NF-Kappa B in murine macrophages by taxol. Cancer Biochem Biophys 1995, I4:265-272.

21. Valerius NH, Stendahl OI, Hartwig JH, Stossel TP: Distribution of actin-binding protein and myosin in neutrophils during chemotaxis and phagocytosis. Adv Exp Med Biol 1982, I4 I: 19-28.

22. McCulloch CA, Knowles GC: Deficiencies in collagen phagocytosis by human fibroblasts in vitro: a mechanism for fibrosis? J Cell Physiol 1993, I55:461-47I.

23. Horowitz MA: The Legionnaires' disease bacterium (Legionella pneumophila) inhibits phagosome-lysosome fusion in human monocytes. J Exp Med 1983, I 58:2108-2I 26.

24. Powell IJ, Harvey RS, Ashwood P, Wolstencroft R, Gershwin ME, Thompson RPH: Immune potentiation of ultrafine dietary particles in normal subjects and patients with inflammatory bowel disease. I Autoimmun 2000, 1 4:99-105.

25. Casini-Raggi V, Kam L, Chong YJ, Fiocchi C, Pizarro TT, Cominelli F: Mucosal imbalance of IL-I and IL-I receptor antagonist in inflammatory bowel disease. A novel mechanism of chronic intestinal inflammation. J Immunol 1995, 154:2434-2440.

26. Lovett D, Kozan B, Hadam M, Resch K, Gemsa D: Macrophage cytotoxicity: interleukin I as a mediator of tumor cytostasis. J Immunol 1986, I 36:340-347.

27. Navarro S, Debili N, Bernaudin JF, Vainchenker W, Doly J: Regulation of the expression of IL-6 in human monocytes. J Immunol I 989, I 42( I 2):4339-4345.

28. Dinarello CA: Interleukin-I and Interleukin-I antagonism. Blood 1991, 77(8): 1627-1652.

29. Dinarello CA, Wolff SM: The role of interleukin-I in disease. New Engl J Med 1993, 328: I06-II3.

30. Stone V, Shaw J, Brown DM, MacNee W, Faux SP, Donaldson K: The role of oxidative stress in the prolonged inhibitory effect of ultrafine carbon black on epithelial cell function. Toxicol In vitro 1998, I 2:649-659.

31. Dransfield I, Buckle AM, Savill JS, McDowall A, Haslett C, Hogg N: Neutrophil apoptosis is associated with a reduction in CD I 6 (FcyRIII) expression. J Immunol 1994, I 53:I254-1263.

32. Grynkiewicz G, Poenie M, Tsien RY: A new generation of $\mathbf{C a}^{2+}$ indicators with greatly improved fluorescent properties. J Biol Chem 1985, 260:3440-3450.

33. Stone V, Tuinman M, Vamvakopoulos JE, Shaw J, Brown DM, Petterson S, Faux SP, Borm P, MacNee W, Michaelangeli F, Donaldson K: Increased calcium influx in a monocytic cell line on exposure to ultrafine carbon black. Eur Respir J 2000, I 5:297-303.
34. Moeller W, Brown DM, Stone V, Kreyling WG: Ultrafine particles cause cytoskeletal dysfunctions in macrophages: role of intracellular calcium. Toxicol Appl Pharmacol 2004 in press.

35. Brown DM, Donaldson K, Borm PJ, Schins RPF, Denhart M, Gilmour PS, Stone V: Calcium and ROS-mediated activation of transcription factors and TNF- $\alpha$ cytokine gene expression in macrophages exposed to ultrafine particles. Am J Physiol Lung Cell Mol Physiol 2004, 286:L344-L353.

36. Pope CA: Epidemiology of fine particulate air pollution and human health: biologic mechanisms and Who's at risk? Environ Health Perspect 2000, I08(Suppl 4):713-723.

37. Bates DJ: Health indices of the adverse effects of air pollution: The question of coherence. Environ Res 1992, 59:336-349.

38. Schwartz J: Air pollution and daily mortality: A review and meta-analysis. Environ Res 1994, 64:36-52.

39. Donaldson K, Stone V, Seaton A, MacNee W: Ambient particle inhalation and the cardiovascular system: Potential mechanisms. Environ Health Perspect 200I, I 09(Suppl 4):523-527.

40. Donaldson K, MacNee W: Potential mechanisms of adverse pulmonary and cardiovascular effects of particulate air pollution (PM 10$)$. Int J Hyg Environ HIth 200I, 203:4 I I-4I 5.

4I. Wilson MR, Lightbody JH, Donaldson K, Sales J, Stone V: Interactions between ultrafine particles and transition metals in vivo and in vitro. Toxicol Appl Pharmacol 2002, I84: I72-I79.

42. Malorni W, losi F, Mirabelli F, Bellomo G: Cytoskeleton as a target in menadione-induced oxidative stress in cultured mammalian cells. Alterations underlying surface bleb formation. Chemico-Biological Interactions 1991, 80(2):217-236.

43. Gilmour PS, Brown DM, Lindsay TG, Beswick PH, MacNee W, Donaldson K: Adverse health effects of PM(I 0) particles: Involvement of iron in generation of hydroxyl radicals. Occup Environ Med 1996, 53( 1 2):817-822.

44. O'Reilly PJ, Philip J, Hickman-Davis JM, Davis IC, Matalon S: Hyperoxia impairs antibacterial function of macrophages through effects on actin. Am J Respir Cell Mol Biol 2003, 28(4):443-450.

45. Cain H, Krauspe R, Kraus B: The cytoskeleton in activated and functionally disordered cells of the macrophage system. Pathol Res Pract 1982, I75(2-3): 162-179.

46. Waterman-Storer CM, Salmon ED: Positive feedback interactions between microtubule and actin dynamics during cell motility. Curr Opin Cell Biol 1999, I I:6I-67.

Publish with Bio Med Central and every scientist can read your work free of charge

"BioMed Central will be the most significant development for disseminating the results of biomedical research in our lifetime. "

Sir Paul Nurse, Cancer Research UK

Your research papers will be:

- available free of charge to the entire biomedical community

- peer reviewed and published immediately upon acceptance

- cited in PubMed and archived on PubMed Central

- yours - you keep the copyright

BiolMedcentral 